\title{
Research budget setback for NSF
}

The Ford Administration's plans to boost spending on basic research in the United States have collided with election-year politics in the House of Representatives, and it now seems likely that support for many areas of research will continue to be eroded by inflation at least for another year. Colin Norman reports from Washington

The House Appropriations Committee, the most powerful of the Congressional budget committees, has approved an appropriations bill for the National
Science Foundation (NSF)-the chief source of federal support for nonbiomedical basic research-which would reduce the foundation's proposed research budget by nearly $\$ 60$ million. The bill would provide $\$ 681$ million for NSF's research programmes next year, a $6 \%$ cost-of-living increase instead of the $20 \%$ boost proposed by the Ford Administration.

The bill will reach the floor of the House during the last week of June, but few upward revisions of the figures should be anticipated there. The Senate will then have its say on the measure, and although it has traditionally been more generous than the House towards NSF, it seems certain that the final, Congressionally approved, budget will fall far short of the Administration's request.

Why is Congress taking such a parsimonious attitude towards NSF? The answer is complicated but, essentially, the Appropriations Committee did not buy the Administration's arguments for increasing research support at a time of general fiscal restraint.

Dr. Guyford Stever, the director of NSF, stated the Administration's rationale most clearly when he described the NSF budget request to reporters last January. "The specific aim" of the proposed $20 \%$ boost in NSF's research support, he said, "is to
- IN a report sharply critical of some of the policies of the Energy Research and Development Administration (ERDA), the Congressional Office of Technology Assessment (OTA) has concluded that "achieving energy independence by 1985 has become all but impossible". Moreover, since $37 \%$ of the oil consumed in the United States last year was imported and the proportion has now reached about $40 \%$, OTA suggests that "even to hold import dependence to the present levels through 1958 would be a formidable achievement. The energy situation is serious and deteriorating".

The report, an analysis of ERDA's programmes and budget requests, suggests that although ERDA has made substantial progress during its first year in forging an energy research and development strategy, there are still serious deficiencies in its approach. And there are even more serious defects in the budget allocations approved by the Office of Management and Budget (OMB).

In particular, OTA argues that ERDA is paying insufficient attention to policies which could affect the energy situation in the next five years. Although ERDA's recently announced energy plan places greater emphasis on conservation, OTA points out that such efforts still account for only $3.8 \%$ of ERDA's budget. Moreover, "the conservation programme has no overriding sense of direction", OTA charges. As for solar energy, OTA suggests that the budgets proposed for solar programmes-particularly the development of heating and cooling unitsare much too small.

In many instances, the fault lies not with ERDA but with OMB. ERDA officials argued, for example, that conservation efforts should receive some $\$ 193$ million in the fiscal year which begins on October 1 , but OMB allowed the agency to request only $\$ 113$ million in its budget application to Congress. Similarly, OMB sliced deeply into ERDA's proposals for solar energy before submitting the agency's budget to Congress.

OTA's analysis has already reached sympathetic ears in the Congress. Though the study was only published last week, drafts have been circulating around Capitol Hill for some time, and they have been used to brief members of key committees. Consequently, on May 25, the House Appropriations Committee approved a bill for ERDA which added $\$ 50$ million to the request for solar energy development and $\$ 10$ million to the budget for conservation efforts.

- In a decision hailed by various nuclear critics, a Federal Appeals Court in New York last week ruled that plutonium cannot be used as a reactor fuel in the United States until the federal government has completed a thorough study of safety and other issues surrounding its use. The immediate impact of the decision will be to delay the start-up of the only plant designed to reprocess commercial reactor wastes in the United States, but the chief effect could be to put off the recycling of plutonium for several years-a pause which nuclear critics are likely to put to good use.

Last November, the Nuclear Regulatory Commission (NRC), the agency responsible for regulating the nuclear industry, announced its intention to issue temporary licences to allow plutonium to be recovered from reactor wastes and recycled as a fuel, pending completion of a massive environmental impact statement on the matter. NRC's decision would have enabled a reprocessing plant, located at Barnwell, South Carolina, to begin limited operations next year. Though NRC made clear that the temporary licences would be revoked if the environmental impact assessment indicates that plutonium recycling is undesirable, nuclear critics were concerned that commercial plutonium use, once started, would be difficult to stop.

The Appeals Court agreed. It directed NRC to complete its environmental study-now scheduled for August-and to conduct public hearings on the issue before approving any licences. The whole process is unlikely to be completed until late next year.

Plutonium recycling is important to the nuclear industry (a fact underlined by the appearance in court of 28 nuclear and electric utility companies) because it will eventually supplement dwindling supplies of uranium. It will also be vitally important for a nuclear programme based on the breeder reactor. But there is widespread concern that commercial use of plutonium will greatly increase the chances of diversion of fissile material to clandestine nuclear weapons, and there is also concern about the health hazards associated with plutonium use. Moreover, it should be noted that the United States is trying to persuade nuclear exporting countries not to transfer reprocessing plants to countries wich do not already possess nuclear weapons, arguing that plutonium reprocessing at present is uneconomic. A decision by the United States to allow domestic reprocessing and plutonium recycling would be viewed abroad as hypocritical, at best. 
counteract the gradual decrease of federal support for basic research, which has declined by about $23 \%$ in terms of constant dollars since 1968". Although research bugets have been going up steadily since the early 1960 s, inflation has been increasing even more sharply and the purchasing power of the research dollar has consequently been shrinking.

Those trends were documented earlier this year in a study prepared for the National Science Board, NSF's policymaking council. The study, Science Indicators 1974, was said to have been particularly influential in persuading the White House Office of Management and Budget (OMB) to back the proposal for a large expansion of federal support for basic research. It showed that total expenditure on basic research (both public and private) increased from $\$ 1,200$ million in 1960 to about $\$ 4,000$ million in 1974 , but that with inflation factored in, research support peaked in 1968 and by 1974 had fallen to the 1965 level.

In its written report on the NSF appropriations bill, however, the House Appropriations Committee didn't agree that basic research is in financial trouble, suggesting instead that "there may be problems of interpretation of the data" in the Science Indicators study. In particular, the committee notes that during the early 1960s, federal agencies tended to maximise their reported support of basic research but more recently, when the watchword has been "relevance", they have tended to classify research as applied whenever possible. Those factors have tended to skew the trends. Equally important, the committee argues that research budgets rose very sharply in the early 1960 s, to reach a high level of federal support, and "this base has continued for the past decade". Moreover, the committee quotes Dr Stever as describing the United States' research and development effort as "still the strongest in the world".

In short, "after carefully considering all factors relating to NSF's research support programs, the Committee feels that the Foundation should be given the budgetary resources needed to continue its current level of research support". In addition, the committee notes that since the research budgets of a few other agencies, such as the Environmental Protection Agency and the Energy Research and Development Administration, have been increased, there seems to have been a marked shift in basic research priorities. The broad policy implications of that shift need to be studied by the new White House Office of Science and Technology policy and, perhaps, by the next Administration, the committee argues.

It should also be noted here, however, that for the past couple of years, NSF has been accorded considerable adverse publicity because of its support of supposedly trivial research projects. Several Senators and Congressmen have managed to get their names into the newspapers by taking cheap shots at research grants with funny-sounding titles and, consequently, there is a strong public perception that the foundation is wasting taxpayers' money. The committee notes in its report that there have been "major concerns in management and administration of NSF programmes", but it stops short of saying out loud that it isn't politically very easy to increase NSF's budget in an election year.

As for other parts of NSF's budget, the House Appropriations Committee was more generous. It increased, by $\$ 9$ million, the Administration's budget request for science education activities, including a $\$ 3$ million addition for courses to acquaint teachers with new school science curricula and new teaching methods. The bulk of NSF's education funds are channelled into universities and colleges, and provide a jealously guarded form of support for higher education. They therefore have considerable popular appeal, which is one reason why the committee preserved them from the axe.

Meanwhile, on May 27, the Senate passed a bill which would broaden NSF's activities and change some of the foundation's management practices. Sponsored by Senator Edward Kennedy, the bill would, among other things, increase public participation in the formulation of NSF policies by increasing the numbers of lay members on NSF committees and advisory panels. It would establish programmes to improve opportunities for members of minority groups to study science and engineering, and it would also establish a new programme of grants to enable state governments to strengthen their science policy machinery. A House-passed version of the bill is, however, much less ambitious and it is likely that some of the provisions in the Senate version will be dropped before the measure is given final Congressional approval. Some NSF officials have also expressed reservations about Kennedy's bill, arguing that it would steer the Foundation further away from its central mission of supporting basic research.

The chief worry of NSF officials, and their clients in the universities and colleges, however, is that Congress now seems likely to prolong the 10 -year erosion of support for basic research.
Peter Pockley reports from Sydney on developments involving the institutions concerned with Australia's science policy

IN spite of strong pressures for its abolition, the Australian Science and Technology Council (ASTEC) has survived. The Prime Minister, $\mathrm{Mr}$ Malcolm Fraser, has announced that the council, established last year by the Whitlam Labor government, will be reconstituted and continue for a further 12 months in an interim capacity. ASTEC, then, becomes one of the few of Labor's initiatives to survive the Fraser razor, and the scientistpoliticians involved in the fight for
ASTEC can be satisfied with their efforts. Survival was necessarily their prime goal, but it appears that this has been offset by the acceptance of uncertainties about the Council's functions and influence. The real bureaucratic battle has yet to be fought and it looks likely that ASTEC, in its reconstituted form, wil have no influence over the 1976-77 Budget priorities.

The science policy clock started ticking in Canberra about four years ago when the Labor Party became the first political party in the country to enunciate a science policy. Before then, the Liberal and Country Parties, through successive Ministers for Education and Science including $\mathrm{Mr}$ Fraser, had repeatedly set their faces against defining, or even attempting to define, a science policy. Spurred on by leading scientists to respond to the ALP initiative, the Liberal government of Mr William McMahon appointed an 11-man Advisory Council for Science and Technology (ACST) in the last months of the government's life. The clock advanced to one o'clock.

On Labor's accession to power in December 1972, the Department of Science was formed. The clock spurted ahead to four o'clock, but dropped back to three early in 1973 when the ACST was axed and no replacement body for advice was appointed. The clock stopped dead for a year while science policy, finance and administration marked time. The visit in 1974 by the Organisation for Economic Cooperation and Development (OECD) to study Australian science policy started the clock again, and by early 1975 it had reached six o'clock with the an- 